\title{
(2) OPEN ACCESS \\ Methylation analysis of MIR200 family in Mexican patients with colorectal cancer
}

\author{
Carlos Rogelio Alvizo-Rodriguez, ${ }^{1}$ Maria de la Luz Ayala-Madrigal, ${ }^{1}$ \\ Jesus Arturo Hernandez-Sandoval, ${ }^{1}$ Helen Haydee Fernanda Ramirez-Plascencia, \\ Christian Octavio Gonzalez-Villaseñor, ${ }^{1}$ Nelly Margarita Macias-Gomez, ${ }^{2}$ \\ Jorge Peregrina-Sandoval, ${ }^{3}$ Jose Miguel Moreno-Ortiz, ${ }^{1}$ \\ Jesus A Valenzuela-Perez, ${ }^{4}$ Jose Alfonso Cruz-Ramos, ${ }^{5}$ \\ Melva Gutierrez-Angulo (1) 1,6
}

For numbered affiliations see end of article.

\section{Correspondence to}

Dr Melva Gutierrez-Angulo, Universidad de Guadalajara, Tepatitlan de Morelos, Jalisco 47600, Mexico; melva.gutierrez@ academicos.udg.mx

Accepted 23 November 2019

Published Online First 23 December 2019

\section{Check for updates}

(C) American Federation for Medical Research 2020. Re-use permitted under CC BY-NC. No commercial re-use. Published by BMJ.

\section{To cite: Alvizo-}

Rodriguez CR, Ayala-

Madrigal MdlL,

Hernandez-Sandoval JA,

et al. J Investig Med

2020;68:782-785.

\section{ABSTRACT}

The present study aimed to analyze the methylation pattern of the MIR200 family in the colorectal tissues and peripheral blood of colorectal cancer (CRC) patients. Previous informed consent, 102 samples of colorectal tissues (tumor and adjacent normal tissues) and 40 peripheral blood samples were collected from CRC patients. Additionally, we included a reference group of 40 blood samples. DNA extraction was done for colorectal tissues and peripheral blood. For methylation-specific PCR, we used bisulfite-treated DNA and controls for methylated and unmethylated DNA were included to each assay. PCR fragments were separated by $6 \%$ polyacrylamide gel electrophoresis. Methylationpositive and methylation-negative results were confirmed by bisulfite genomic sequencing technique. We analyzed 102 colorectal tissues and 40 blood samples from 51 CRC patients. MIR200B/ MIR200A/MIR429 methylation analysis discloses no differences among tissues ( $p>0.05$ ). However, MIR200C/MIR141 methylation showed differences between colorectal tissues and peripheral blood of CRC patients $(p<0.0001)$ and mainly methylated alleles were observed in peripheral blood. These findings suggest a tissue-specific methylation pattern for the MIR200C/MIR141 promoter.

\section{INTRODUCTION}

The addition of a methyl group in position 5 of the cytosines occurring in $\mathrm{CpG}$ islands and nearby shores leads to "the fifth base" five methyl-cytosine $(5-\mathrm{mC})$. The presence of $5-\mathrm{mC}$ is related to gene expression regulation, genomic imprinting, $\mathrm{X}$ inactivation, and tissue-specific regulation. ${ }^{12}$ In colorectal cancer (CRC), hypermethylation-mediated gene silencing has been described in protein-coding genes such as RUNX3, CACNA1G, IGF2, and $\mathrm{MLH} 1 .^{3}$ Moreover, this epigenetic modification has been reported in microRNAs (miRNAs). ${ }^{4}$ The miRNAs are typically 23 nucleotides long and influence gene regulation. ${ }^{5}$ Among the miRNAs, MIR200 family has been related

\section{Significance of this study}

What is already known about this subject?

- miRNAs influence gene expression.

- Dysregulation of MIR200 family has been related to metastasis in colorectal cancer (CRC).

What are the new findings?

- Methylation status of MIR200 family in Mexican patients with CRC.

- High proportion of methylated alleles of the MIR200C/MIR141 cluster in peripheral blood of CRC patients and reference group.

\section{How might these results change the focus of research or clinical practice? \\ - The results found in peripheral blood suggest that different tissues and several CpG sites must be included during the design of methylation assays to find the best biomarker in multifactorial diseases.}

to epithelial-mesenchymal transition (EMT) found in CRC. ${ }^{6}$ The MIR200 family consists of the following five members clustered in two loci: MIR200B, MIR200A, and MIR429 are located on 1p36.33, whereas MIR200C and MIR141 are on $12 \mathrm{p} 13.3$. The respective $\mathrm{CpG}$ island is located on -378 to +2568 for MIR200B/MIR200A/MIR429 and between -343 and -115 nucleotides for MIR200C/ MIR141. ${ }^{78}$ The present study aimed to analyze the methylation pattern of the MIR200 family in the colorectal tissues and peripheral blood of CRC patients.

\section{MATERIALS AND METHODS \\ Patients and samples}

Post histopathological confirmation of CRC, tumor and adjacent normal tissues were collected from surgically removed biopsy samples of 51 Mexican patients. These 51 patients had not received any prior treatment. The peripheral blood samples could be obtained 
Table 1 Characteristics of CRC patients and reference group

\begin{tabular}{llllll}
\hline & $\begin{array}{l}\text { Mean } \\
\text { age }\end{array}$ & $\begin{array}{l}\text { Age range } \\
(\%)\end{array}$ & $\begin{array}{l}\text { Gender } \\
(\%)\end{array}$ & $\begin{array}{l}\text { Tumor } \\
\text { localization } \\
(\%)\end{array}$ & $\begin{array}{l}\text { Stage } \\
(\%)\end{array}$ \\
\hline $\begin{array}{l}\text { CRC patients } \\
\mathrm{n}=51\end{array}$ & 61 & $\begin{array}{l}30-50: 22 \\
51-70: 53\end{array}$ & $\begin{array}{l}\text { F: } 33 \\
\text { M: } 67\end{array}$ & $\begin{array}{l}\text { Colon: } 59 \\
\text { Rectum: } 41\end{array}$ & $\begin{array}{l}\text { 0-II: } 28 \\
\text { III-IV: } 68\end{array}$ \\
& & $+71: 25$ & & & NA: 4 \\
Reference & 51 & $\begin{array}{l}30-50: 50 \\
\text { n=40 }\end{array}$ & F: 42 & --------- & ------- \\
& & $+71: 0$ & M: 58 & & \\
\hline
\end{tabular}

CRC, colorectal cancer; F, female; M, male; NA, not available.

from 40 of these patients, and additionally 40 blood samples of donors were included as a reference group. All subjects were admitted for treatment at Hospital Civil "Juan I. Menchaca" during the period 2016-2017 and signed an informed consent in accordance with the Declaration of Helsinki. The project was approved by the Local committee in Bioethics (CUA/CEI/081/2016).

\section{DNA extraction}

After histopathological classification as normal mucosa or tumor tissue, the DNA was extracted with the High Pure PCR Template preparation kit (Roche Diagnostics \#11796828001). The tissues were maintained in RNA later (Ambion, \#AM7020) at $-20^{\circ} \mathrm{C}$ until the DNA isolation. DNA extraction from blood samples was carried out according to Miller et al and DTAB/CTAB protocols. ${ }^{9}{ }^{10}$ DNA concentration and purity were determined with a spectrophotometer at 260 and $280 \mathrm{~nm}$. DNA was storage at $-80^{\circ} \mathrm{C}$ until the time of methylation-specific PCR (MS-PCR).

\section{DNA bisulfite conversion}

Prior to amplification, all DNA samples were converted using EZ DNA methylation-gold kit at a concentration of $100 \mathrm{ng} / \mu \mathrm{L}$ (Zymo Research \#D5008), according to the manufacturer's instructions. DNA conversion process transformed unmethylated cytosines to uracil, while methylated cytosines were not modified. Additionally, human methylated and unmethylated DNA controls from HCT116 DKO cell line were used during DNA conversion to assess the reaction efficiency (Zymo Research \# D5014).

\section{Methylation-specific PCR}

Converted DNA was subjected to MS-PCR with primers using the protocol described by Davalos et al. ${ }^{7}$ Briefly, the PCR reactions for all assays were performed using $100 \mathrm{ng} / \mu \mathrm{L}$ of DNA in a volume of $25 \mu \mathrm{L}$ mixed with $1 \mathrm{X}$ PCR buffer, $1.5 \mathrm{mM} \mathrm{MgCl}, 200 \mu \mathrm{M}$ dNTPs, 5 pmol of each primer, and $2 \mathrm{U}$ of Platinum Taq DNA polymerase.
Previously converted controls for methylated and unmethylated DNA were included in PCR reactions. All assays were performed in duplicate. For the MIR200B/MIR200A/ MIR429 cluster, the primers for methylated and unmethylated DNA were 5'-GAGCGGAGATTGGTTAGC-3' and 5'-TTATTGTTTCGTCGTTTTCGA-3' and 5'-TAGG AGTGGAGATTGGTTAGT-3' and 5'- ATTGTTTTGTTG TTTTTGAAATTT-3', respectively. PCR steps for methylated DNA included an initial denaturation at $94^{\circ} \mathrm{C}$ for $5 \mathrm{~min}$ and 37 cycles of $94^{\circ} \mathrm{C}$ for $30 \mathrm{~s}, 56.4^{\circ} \mathrm{C}$ for $30 \mathrm{~s}$, and $72^{\circ} \mathrm{C}$ for $30 \mathrm{~s}$, whereas the cycling conditions for unmethylated DNA were similar except for the annealing temperature of $49.2^{\circ} \mathrm{C}$. The primers for MIR200C/MIR141 cluster were 5'-GCGTTGGTTGTTCGGTAGGC-3' and 5'-GACAACCTTTCCCGACCCG-3' for methylated DNA and 5'-GTGTTGGTTGTTTGGTAGGT-3' and 5'-AACAACCTTTCCCAACCCA-3' for unmethylated DNA. PCR conditions for methylated and unmethylated DNA were similar; 35 cycles of $94^{\circ} \mathrm{C}$ for $30 \mathrm{~s}, 70.2^{\circ} \mathrm{C}$ for $30 \mathrm{~s}$, and $72^{\circ} \mathrm{C}$ for $30 \mathrm{~s}$, except for the annealing temperature of $60^{\circ} \mathrm{C}$ used for unmethylated DNA.

\section{Electrophoresis}

PCR amplicons were detected in a 6\% polyacrylamide gel electrophoresis stained with $\mathrm{AgNO}_{3}$. A PCR fragment of size 141 and 149 base pairs (bp) was considered methylated and unmethylated, respectively, for the MIR200B/ MIR200A/MIR429 cluster, while a 240 bp PCR fragment size was considered both methylated and unmethylated for the MIR200C/MIR141 cluster.

\section{Bisulfite genomic sequencing}

Bisulfite genomic DNA sequencing was performed on samples positive for methylated and unmethylated DNA (ABI PRISM 3110, ThermoFisher Scientific). In all 12 CpG sites were sequenced. CpGviewer software was used for reading and aligning the DNA sequences generated by Sanger sequencing. ${ }^{11}$

\section{Statistical analysis}

The Fisher's Exact test was used to compare methylation frequencies and $\mathrm{p}<0.05$ was considered as significant.

\section{RESULTS}

We analyzed 102 colorectal tissue samples (tumor and adjacent normal tissues) from 51 CRC patients (67\% men) with an average age of 61 years. Additionally, 40 peripheral blood samples from the same patients and 40 from healthy individuals (reference group) were included in the methylation assay. Table 1 shows the characteristics of both groups.

Table 2 Methylation analysis of MIR200B/MIR200A/MIR429 cluster in CRC patients and reference group

\begin{tabular}{|c|c|c|c|c|}
\hline \multirow[b]{2}{*}{ MIR200B/MIR200A/MIR429 cluster } & \multicolumn{3}{|l|}{ CRC patients } & \multirow{2}{*}{$\begin{array}{l}\text { Reference group } \\
\text { Peripheral blood } \\
n=40(\%)\end{array}$} \\
\hline & $\begin{array}{l}\text { Tumor tissue* } \\
n=50(\%)\end{array}$ & $\begin{array}{l}\text { Adjacent normal tissue* } \\
n=50(\%)\end{array}$ & $\begin{array}{l}\text { Peripheral blood* } \\
\mathrm{n}=40(\%)\end{array}$ & \\
\hline Methylated and unmethylated alleles & $50(100)$ & $48(96)$ & $40(100)$ & $40(100)$ \\
\hline Only methylated alleles & 0 & $2(4)$ & 0 & 0 \\
\hline Only unmethylated alleles & 0 & 0 & 0 & 0 \\
\hline
\end{tabular}

${ }^{*}$ Comparisons among the colorectal tissues and peripheral blood of CRC patients and between the groups were not significant ( $\left.p>0.05\right)$.

CRC, colorectal cancer. 
Table 3 Methylation analysis of MIR200C/MIR141 cluster in CRC patients and reference group

\begin{tabular}{llllll}
\hline & CRC patients & & \multicolumn{2}{c}{ Reference group } \\
\cline { 2 - 3 } MIR200C/MIR141 cluster & $\begin{array}{l}\text { Tumor tissue } \\
\mathrm{n}=51(\%)^{*}+\end{array}$ & $\begin{array}{l}\text { Adjacent normal tissue } \\
\mathrm{n}=51(\%)^{*}\end{array}$ & $\begin{array}{l}\text { Peripheral blood } \\
\mathrm{n}=40(\%) \dagger\end{array}$ & $\begin{array}{l}\text { Peripheral blood } \\
\mathrm{n}=40(\%)\end{array}$ \\
\hline Methylated and unmethylated alleles & $48(94)$ & $49(96)$ & $8(20)$ & $5(12.5)$ \\
Only methylated alleles & $2(4)$ & $2(4)$ & $32(80)$ & $35(87.5)$ \\
Only unmethylated alleles & $1(2)$ & $0(0)$ & 0 & 0 \\
\hline
\end{tabular}

${ }^{*}$ Comparisons between colorectal tissues of CRC patient were not significant ( $\left.p>0.05\right)$.

tComparisons between colorectal tissues versus peripheral blood of CRC patients or versus reference group were significant $(p<0.0001)$.

CRC, colorectal cancer.

The methylation analysis of MIR200B/MIR200A/MIR429 and MIR200C/MIR141 clusters did not reveal significant differences between tumor and adjacent normal tissues $(p>0.05)$ (tables 2 and 3). Both of these clusters mostly exhibited a mix of methylated and unmethylated alleles.

However, in the MIR200C/MIR141 cluster, we observed mainly methylated alleles in the peripheral blood compared with colorectal tissues from CRC patients $(\mathrm{p}<0.0001)$. The methylation pattern in the reference group was similar to that observed in the peripheral blood of patients with CRC (table 3). Figure 1 depicts the methylation pattern of the MIR200C/MIR141 cluster in the peripheral blood and colorectal tissues of CRC patients. Samples positive for methylated and unmethylated DNA were confirmed by bisulfite genomic DNA sequencing (figure 2).

\section{DISCUSSION}

DNA methylation-mediated silencing of gene expression in cancer cells promotes tumor development. ${ }^{12}{ }^{13}$ Different studies have focused on methylation pattern of cancerassociated genes to identify tumor-specific biomarkers effective for developing targeted therapies. ${ }^{13}$ In the current study, we analyzed the methylation status of MIR200 family in samples of the colorectal tissues (adjacent normal and tumor tissues) and peripheral blood from CRC patients as well as in blood samples of a reference group of healthy individuals. The absence of significant differences between the tumor and adjacent normal tissues observed in the present study is consistent with the previous findings for both the MIR200 family clusters. ${ }^{71415}$ Davalos et al analyzed the MIR200 family methylation pattern in the colorectal tissues of 25 CRC patients and RKO and HCT116 cell lines. They detected only methylated sites in RKO cells but

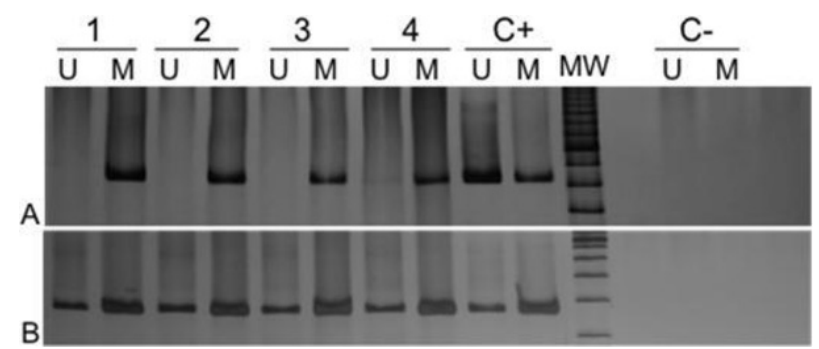

Figure 1 Methylation pattern of MIR200C/MIR141 cluster in CRC patients; The figure shows mainly methylated alleles in the peripheral blood (1A), and methylated and unmethylated alleles in adjacent normal tissues (1B) (MW: Molecular weight marker of $50 \mathrm{bp}, \mathrm{C}+$ : positive control and $\mathrm{C}-$ : negative control, $\mathrm{M}$ (methylated), U (unmethylated)). CRC, colorectal cancer. unmethylated ones in HCT116 cells. In colorectal tissues, they reported a predominant mix of unmethylated and methylated alleles with only the MIR200C/MIR141 cluster exhibiting hypermethylation in $40 \%$ of tumor samples. ${ }^{7}$ Wiklund et al analyzed both clusters and found more hypermethylated DNA in invasive bladder cancer than in superficial tumors and normal urothelium $(n=5)$; moreover, the same pattern was observed in undifferentiated cell lines but not in differentiated cells. ${ }^{16} \mathrm{Li}$ et al reported hypermethylation of MIR200C in tumor tissue and not in adjacent nontumor tissues in 39 gastric cancer samples (63\% vs $54.6 \%$, respectively, $\mathrm{p}<0.01) .{ }^{14}$ Hypomethylation of MIR200B/ MIR200A/MIR429 cluster has been reported in various liver and pancreatic cancer cell lines, ${ }^{17} 18$ whereas hypermethylation has been detected in transformed cells and breast cancer cells with mesenchymal phenotype. ${ }^{19}$

Furthermore, in prostate and breast cancer cell lines, the MIR200C/MIR141 promoter methylation is correlated with expression and presumably with EMT. ${ }^{720}$ In 14 prostate cancer biopsies, a common methylation pattern of the MIR200C/MIR141 cluster was observed in both normal and tumor tissues; however, when the authors divided the promoter region in three sections, they found variable results with higher percentage of methylation in regions 2 and 3 than in region $1 .^{15}$ In our methylation analysis that included a part of region 1, only $4 \%$ of CRC patients had methylated alleles in the cluster. Since these patients showed mainly methylated alleles for MIR200C/MIR141 in blood, a tissuespecific methylation pattern can be inferred. In samples of the reference group, we observed the same pattern of methylated alleles. Although methylation regulates tissuespecific gene expression, it is possible that the methylated MIR200C/MIR141 alleles modulate the expression of these miRNAs in the peripheral blood. Evidence supporting the addition of the region analyzed in this study to the list of tissue-specific differentially methylated regions, which are contiguous genomic segments with different methylation patterns across various biological samples and located around the promoter or within the gene, even in intergenic

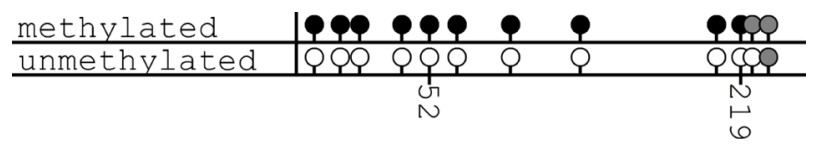

Figure 2 Lollipop plot shows 12 CpG sites of MIR200C/ MIR141 cluster in methylated and unmethylated DNA; black and white circles represent methylated and unmethylated cytosines respectively; the $\mathrm{CpG}$ sites not aligned with respect to reference sequence are shown in gray circles. 
regulatory regions, is accumulating. ${ }^{21}$ This is supported by Vrba et al, who analyzed the methylation and expression of MIR200C/MIR141 in human mammary epithelial cells and human mammary fibroblasts and found a cell type-specific repression by DNA methylation of this cluster in HMF. ${ }^{22}$ They also included the MIR200B/MIR200A/MIR429 cluster and a similar pattern was seen; however, the repression was induced by DNA methylation and $\mathrm{H} 3 \mathrm{~K} 27 \mathrm{me} 3 .{ }^{22}$ Additionally, the expression levels of MIR200C/MIR141 cluster in blood samples of control individuals have been analyzed and lower expression of MIR141 has been reported compared with MIR200C. ${ }^{23}{ }^{24}$ Thus, results from our study and previous literature seem to indicate that the region analyzed here could be involved in the regulation of MIR141 gene.

The lack of significant differences between the tumor and adjacent normal tissues could be related to the small sample size, and this is the main limitation of the current study. Moreover, MS-PCR technique could be considered as another limitation because it is related with a high frequency of falsepositive results; however, to overcome this limitation, bisulfite genomic sequencing was performed for confirming a few positive and negative results. The findings of this study highlight the importance to include several tissues in the analysis to identify the best biomarker for CRC.

In conclusion, Mexican patients with CRC exhibited a methylation pattern similar to the MIR200 family in tumor and adjacent normal tissues; however, in the MIR200C/ MIR141 cluster, methylated alleles were more frequently detected than unmethylated ones in the peripheral blood of such patients. These findings could be considered as tissuespecific methylation for the MIR141 gene.

\author{
Author affiliations \\ ${ }^{1}$ Doctorado en Genética Humana, Departamento de Biología Molecular y \\ Genómica, Centro Universitario de Ciencias de la Salud, Universidad de \\ Guadalajara, Guadalajara, Jalisco, Mexico \\ ${ }^{2}$ Departamento de Promoción, preservación y desarrollo de la Salud, Centro \\ Universitario del Sur, Universidad de Guadalajara, Ciudad Guzman, Jalisco, \\ Mexico \\ ${ }^{3}$ Biología Celular y Molecular, Centro Universitario de Ciencias Biologicas y \\ Agropecuarias, Universidad de Guadalajara, Zapopan, Jalisco, Mexico \\ ${ }^{4}$ Hospital Civil de Guadalajara Dr Juan I Menchaca, Guadalajara, Jalisco, \\ Mexico \\ ${ }^{5}$ Departamento de Enseñanza y Capacitacion, Instituto Jaliciense de \\ Cancerologia, Guadalajara, Jalisco, Mexico \\ ${ }^{6}$ Departamento de Ciencias de la Salud, Centro Universitario de los Altos, \\ Universidad de Guadalajara, Tepatitlan de Morelos, Jalisco, Mexico
}

Acknowledgements CRAR, JAHS, HHFRP, and COGV are students of PhD program in Human Genetics and were supported by CONACyT scholarship. We thank Dr Horacio Rivera for the critical review of the manuscript. We would like to thank Editage (www.editage.com) for English language editing.

Contributors MGA, MLAM, NMMG, JPS, and JMMO have been contributed to design of the work and interpretation of data. Moreover, they have approved the final version. CRAR, JAHS, HHFRP, and COGV have been worked with acquisition and analysis of molecular data. JAVP and JACR have been worked with acquisition and analysis of clinical data of colorectal cancer patients.

Funding The project was supported by Universidad de Guadalajara.

Competing interests None declared.

Patient consent for publication Not required.

Provenance and peer review Not commissioned; externally peer reviewed.

Data availability statement All data relevant to the study are included in the article or uploaded as supplementary information.
Open access This is an open access article distributed in accordance with the Creative Commons Attribution Non Commercial (CC BY-NC 4.0) license, which permits others to distribute, remix, adapt, build upon this work noncommercially, and license their derivative works on different terms, provided the original work is properly cited, an indication of whether changes were made, and the use is non-commercial. See: http://creativecommons.org/ licenses/by-nc/4.0/.

\section{ORCID iD}

Melva Gutierrez-Angulo http://orcid.org/0000-0003-3848-8892

\section{REFERENCES}

1 Portela A, Esteller M. Epigenetic modifications and human disease. Nat Biotechnol 2010;28:1057-68.

2 Zhang W, Xu J. DNA methyltransferases and their roles in tumorigenesis. Biomark Res 2017;5.

3 Ogino S, Kawasaki T, Kirkner GJ, et al. Evaluation of markers for CpG island methylator phenotype (CIMP) in colorectal cancer by a large population-based sample. J Mol Diagnostics 2007:9:305-14.

4 Wang S, Wu W, Claret FX. Mutual regulation of microRNAs and DNA methylation in human cancers. Epigenetics 2017:12:187-97.

5 Cipolla GA. A non-canonical landscape of the microRNA system. Front Genet 2014;5:337.

6 O'Brien SJ, Carter JV, Burton JF, et al. The role of the miR-200 family in epithelial-mesenchymal transition in colorectal cancer: a systematic review. Int I Cancer 2018;142:2501-11.

7 Davalos V, Moutinho C, Villanueva A, et al. Dynamic epigenetic regulation of the microRNA-200 family mediates epithelial and mesenchymal transitions in human tumorigenesis. Oncogene 2012;31:2062-74.

8 Neves R, Scheel C, Weinhold S, et al. Role of DNA methylation in miR200c/141 cluster silencing in invasive breast cancer cells. BMC Res Notes 2010:3:219.

9 Gustincich S, Manfioletti G, Del Sal G, et al. A fast method for highquality genomic DNA extraction from whole human blood. Biotechniques 1991;11:298-300.

10 Miller SA, Dykes DD, Polesky HF. A simple salting out procedure for extracting DNA from human nucleated cells. Nucleic Acids Res 1988;16:1215.

11 Carr IM, Valleley EMA, Cordery SF, et al. Sequence analysis and editing for bisulphite genomic sequencing projects. Nucleic Acids Res 2007;35:e79.

12 Durso DF, Bacalini MG, do Valle Ítalo Faria, et al. Aberrant methylation patterns in colorectal cancer: a meta-analysis. Oncotarget 2017;8:12820-30.

13 Mikeska T, Craig J. DNA methylation biomarkers: cancer and beyond. Genes 2014;5:821-64

14 Li Y, Nie Y, Tu S, et al. Epigenetically deregulated miR-200c is involved in a negative feedback loop with Dnmt3a in gastric cancer cells. Oncol Rep 2016:36:2108-16.

15 Lynch SM, O'Neill KM, McKenna MM, et al. Regulation of miR-200c and miR141 by methylation in prostate cancer. Prostate 2016;76:1146-59.

16 Wiklund ED, Bramsen JB, Hulf T, et al. Coordinated epigenetic repression of the miR-200 family and miR-205 in invasive bladder cancer. Int J Cancer 2011;128:1327-34

17 Li A, Omura N, Hong S-M, et al. Pancreatic Cancers Epigenetically Silence SIP1 and Hypomethylate and Overexpress miR-200a/200b in Association with Elevated Circulating miR-200a and miR-200b Levels. Cancer Res 2010;70:5226-37.

18 Li L, Tang J, Zhang B, et al. Epigenetic modification of miR-429 promotes liver tumour-initiating cell properties by targeting $\mathrm{Rb}$ binding protein 4 . Gut 2015;64:156-67.

19 Eades G, Yao Y, Yang M, et al. miR-200a regulates SIRT1 expression and epithelial to mesenchymal transition (EMT)-like transformation in mammary epithelial cells. J Biol Chem 2011;286:25992-6002.

20 Vrba L, Jensen TJ, Garbe JC, et al. Role for DNA methylation in the regulation of miR-200c and miR-141 expression in normal and cancer cells. PLoS One 2010:5:e8697.

21 Peters TJ, Buckley MJ, Statham AL, et al. De novo identification of differentially methylated regions in the human genome. Epigenetics Chromatin 2015;8:6.

22 Vrba L, Garbe JC, Stampfer MR, et al. Epigenetic regulation of normal human mammary cell type-specific miRNAs. Genome Res 2026;2011.

23 Antolín S, Calvo L, Blanco-Calvo M, et al. Circulating miR-200c and miR-141 and outcomes in patients with breast cancer. BMC Cancer 2015:15:297.

24 Zhu SH, XC H, Wang L. Correlation analysis of miR-200b, miR-200c, and miR141 with liver metastases in colorectal cancer patients. Eur Rev Med Pharmacol Sci 2017;21. 